\title{
Changing property regimes in the aquatic environments of the Lower Mekong Basin in Southern Laos and Northern Thailand
}

Tomoуa Акімісні

Research Institute for Humanity and Nature, Kyoto, 603-8047, Japan Tel: 075-707-2410, E-mail: akimichi@chikyu.ac.jp
ABSTRACT This paper principally deals with changing aspect of aquatic property regimes in tropical Southeast Asia to understand how local hegemony plays an important role both of freshwater resource use and local development, with special reference to migratory fish (white fish) and non-migratory fish (black fish) in various aquatic environments. In tropical Southeast Asia, freshwater resources have deteriorated to a great degree. This is due to anthropogenic alteration of the environment owing to industrial and agricultural development, and uncontrolled and mismanaged exploitation of resources. To protect from environmental degradation and resource depletion, both the government and local communities have tackled the problem, adopting various sets of formal and informal measures. In this paper, case studies of freshwater resource use in Laos and Thailand and its change over time are examined. In the Lower Mekong Basin of southern Laos, 68 fish conservation zones (FCZs) were established as sanctuaries in 63 fishing communities with a support of international agencies during the period of 1993 and 1997. As migratory fish did not increase except some cyprinid species, and thus it turned to be partly a failure, some local communities converted FCZs' sanctuary to a common property for a limited social purpose since around 2000s. In one community, FCZ was auctioned for public use only for a few days and then open to community members. In paddy field system in Laos and elsewhere in Southeast Asia (eg., Thailand and Cambodia), fishing in paddies is open access while ponds used to be a common property and were used for communal fishing (phaa nong) mainly for non-migratory fish. Since around 2000s, communal ponds in some communities of Laos and Thailand have come to be privatized so as to contrive to raise funds for community development, although big ponds tend to be maintained as a common property. Also, some individuals claimed an exclusive use of the pond for aquaculture or lotus harvest. Elsewhere, ponds were auctioned for a few days' exclusive use, and then were open to public. The change from communal to privatized property through a sale, a one-sided occupation, or auction system (as temporal privatization), does not simply suggest a collapse of community solidarity, but generally a rise of social hegemony to realize community development by collecting funds. These examples clearly show that property regimes are not fixed but flexible, depending on the increasing social demand as in the cases of FCZs in the Lower Mekong Basin, and of privatization of ponds in Laos and Thailand. Whether community's decision is appropriate or not in terms of social development and resource management, is a question of sustainable community fishery in Southeast Asia.

Key words: white fish, black fish, community-based resource management, change in property regimes, Lower Mekong Basin, Laos and Thailand

\section{INTRODUCTION}

During the past few decades in tropical Southeast Asia, aquatic environments have deteriorated in terms of water quality and loss of bio-diversity. This is due to anthropogenic alteration of the environment such as industrial and agricultural development, discharge of pollutants, dam construction, and above all, uncontrolled and mismanaged exploitation of resources. To protect from environmental degradation, both the government and local communities have tackled the problem, manipulating various sets of formal and informal measures.

In terms of property regimes, there is a conventional typology; open access (=non-property), private property, 
public property, common property (Cole, 2002) and royal property (Tisdell, 1999) or sanctuary (Akimichi, 1995; 2004a). Among of these categories, resource management measures are operated differently. First, to establish sanctuary for environmental protection is definitely powerful measures to exclude any human intervention. Indeed, sanctuary and nature reserve are being enforced effectively by the government while national trust movement is another type of nature protection promoted by collective owners. Secondly, communal property approach has been proclaimed as effective to control resource use among collective owners and by excluding outsiders. Thirdly, both private property and open access are not relevant to resource management as private property regime is uncontrolled by anyone else while open access may lead to the tragedy as a resource has no owner and no one can claim the right to exclude anyone else (Cole, 2002).

It is important here to identify what kinds of property regimes are attached to individual resource in a given space. Aquatic resources exist in various forms and nature. In freshwater domain, fish live in rivers, ponds, flood plains, and often found in paddies, and they move horizontally and vertically in the aquatic system. Frogs, snails, crabs, insects and water weeds are found extensively and these aquatic resources are also utilized according to the season and depending on abundance. Overall, aquatic resources are usually regarded as common property. If so, we may be keen to the evidence if any property regimes shift occurs, and what drivers are associated with the change.

\section{MATERIALS AND METHODS}

\section{Study site}

The study sites are located along the Lower Mekong Basin of northern Thailand and southern Laos. Mekong River in southern Laos bordering Cambodia to the south is known as Siphandone wetlands, namely "four thousands islands" where there are many large and small islands in the midst of main stream. Fishing is most active along this area. Deep pools are found here and there that become important fish shelters during the dry season. In inland communities on both sides of the Mekong River, small streams and a number of large and small ponds are used for small-scale fishing. These ponds are often vulnerable to be inundated during the flooding period. In northern Thailand and Laos, Mekong River flows through the national border in the narrow valley. Only two major tributaries of the Mekong River are Kok and Ing rivers on the right bank (Thailand side) where numerous ponds and wetlands develop. Study villages are inhabited by Lao or Thai speaking populations in the lowland Mekong River watersheds, and their subsistence are focused on paddy rice cultivation and freshwater fishing.

\section{Seasonal fish migration}

In the Mekong River Basin, there is a marked seasonality. During June and October, it is wet and there is much rain. In particular, in August and September the area is prone to flooding. While between November and May it is dry and rainless, and serious drought often occurs. In line with the seasonal availability of rain and river waters, most of local communities in this area have adopted a single cropping system of paddy rice cultivation, combined with fishing and gathering. Local communities along the Mekong River and its major tributaries, fishing is an important subsistence and commercial pursuit. Gill net, long line, hand line, cast net, and various types of basketry trap are utilized. While in inland paddy riceproducing communities, fishing is a subsidiary activity. A variety of fishing techniques are employed such as traps, weir, scoop net, drag net, hand net, hook and line in small streams, canal, ponds and paddy fields.

In line with seasonal change of water mass, some fish in the Mekong River migrate for a long distance as the onset of rainy season from downstream to upperstream for spawning. These long-distance migratory fish are generally called 'white fish' that include cyprinids (Cirrhinus, Hampala, Puntius, Leptobarbus, Osteochilus, Labeo), Pangasiidae (Pangasius), Siluridae (Wallago, Kryptoperus) and Notopteridae (Notopterus). Often, these fish move from the Mekong River to tributaries, flood plains and inundated land. While some other fish do not migrate in the long distance, but stay in the swamps and flood plains year round and only seasonally enter into paddy fields in the wet season. These fish are called as 'black fish' that include Claridae (Clarias), Channidae (Channa), Bagridae (Mystus), and Anabantidae (Anabas, Trichogaster) (Baird et al. 1999; Mekong River Commission, 2002; Poulsen et al. 2004) (Photograph 1). Furthermore, short-distance migratory fish that move between flood plains and river channels are called gray fish (Welcomme, 1985).

\section{Fieldwork}

In this paper, I will argue about the change in the access rights to aquatic resources, using data derived from my own fieldwork on freshwater fishing practices in southern Laos and northern Thailand. Fieldwork was conducted 

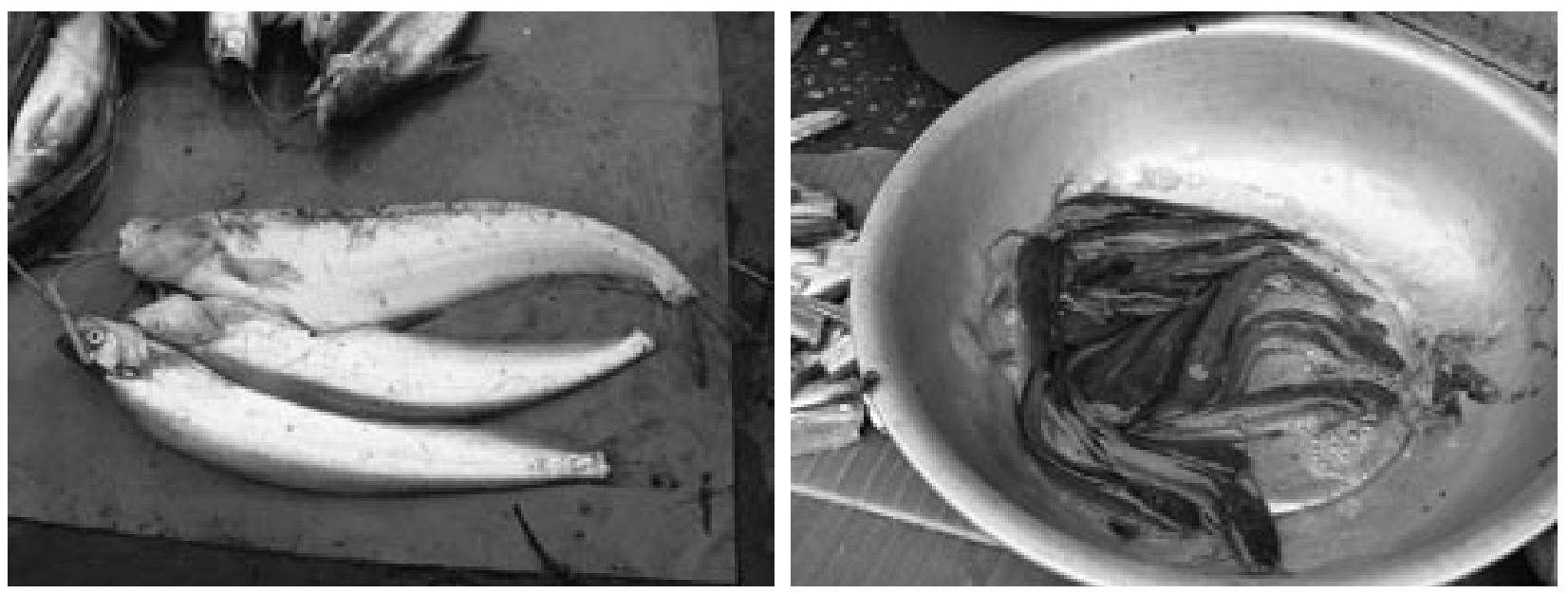

Photo 1. White fish (Micronema sp.) left, and Black fish (Clarias sp.) right.

between 2002-2006, in southern Laos and northern Thailand. Data were obtained through interviews and direct observation in anthropological discourse. Study was conducted as a part of the research project, entitled as 'A trans-disciplinary study on the regional eco-history in tropical monsoon Asia: 1945-2005' with a five-year research grant from Research Institute for Humanity and Nature, Japan and also a part of the research program on the 'Anthropology of Resources" headed by Motomitsu Uchibori.

\section{RESULTS}

\section{White fish and property regime shift in southern Laos}

In southern Laos, fish conservation project was set up in 1993. The project aimed to enhance communities' fishery potential with the conservation of river dolphin that inhabits the border area of Laos and Cambodia. It continued until 1997, in which major program was to establish 'fish conservation zones' (FCZs) to protect fish resources in each Lao lum (lowland Lao people) community along the Mekong mainstream. FCZs usually include deep pools that become dry-season refuges for various kinds of fish (Baird et al. 1998). FCZ is locally termed as vang sanguwane (lit., vang: deep pool, sanguwane: conservation zone). Initially, $59 \mathrm{FCZs}$ were established in 54 communities and later $68 \mathrm{FCZs}$ in 63 communities were completed. Size of each FCZ varies between 0.25 ha and 18 ha (average=3.52 ha) (Baird and Flaherty, 1999). Similar project followed the first one in 1997 in the Siphandone wetlands in southern Laos and it continued for three years until 1999 (Daconto, 2001). In this project, 13 communities newly took part in, and 81
FCZs were set up in total.

These two projects were initiated by a topdown approach. Project members visited each village and explained the concept and significance of fish conservation zone to villagers. If agreed in the village meeting, villagers decided to enclose certain area that includes a deep pool. At the same time, certain additional rules and penalty were agreed. As an aid to community's positive cooperation, housing materials for construction were donated from the project to individual community. In this regard, FCZs project is a co-management type of fish conservation practice, rather than government-based management.

After the project being completed, Baird summarized the project as follows; FCZs project is generally successful as 51 fish species were reported to increase significantly. These are predominantly sedentary species. However, some migratory species did not increase except Mekongina erythrospila, Labiobarbus leptocheilus and other cyprinid species. It is evident that benefits obtained by setting up the fish conservation zone depend on the ecological difference of fish species (Baird and Flaherty, 1999).

During the course of FCZs implementation, there was a trial by some community leaders to demonstrate the effects of FCZs by comparison of fish yields from both within and outside of the FCZs, using gill net of 6,8 and $10 \mathrm{~mm}$ mesh size. The experiment was held in October and November, and continued for three years between 2002 and 2004. The result showed that there is less catch in both areas, and that there is no difference of fish yields between the two. One of the community leaders told me that the idea and practice of FCZs was partly effective as sanctuaries ensured dry season refuges for 
many kinds of fish, and provided educational opportunity to instruct fishermen about the role and function of conservation measures. Despite this, he concluded that FCZs project was inappropriate and partly failed as fish did not increase. Thus, community fishery in the Lower Mekong Basin bears needs to be examined, taking into interactions account of both government-based and community-based approaches (Claridge et al. 1997).

After the project being over, poaching increased in some villages. Conflict and debates were intensified over the observance of rules between village leaders and among villagers. In some villages, leaders decided to apply severer penalty to poachers than before. Yet, as a fine to poachers is not decided by the same standard, the project has posed a serious question regarding social disparity in Lao lum fishing communities.

Around 2000, five riverine communities along the Mekong River have resolved to propose a new conservation rule as community-based resource management measures, instead of the former FCZs concept. People declared vang xum xone or community's deep pool (lit., xum xone: local community) (Akimichi, 2006, 2008a). In this framework, fish conservation zone can be lifted for one or two days when villagers need fish or the budget for public benefit such as road construction, repair of school and temple, or entertaining government officers by serving fish food who visit the village for inspection or administrative work. Also, in one village, auction system was introduced when fish is found abundant. Three to five days were open and exclusively utilized by the person who obtained the fishing rights. Auctioned price was two millions KP (ca. US\$ 200) per day, but the price could be changed, depending on the total amount of catch during the fishing operation.

Generally, the decision to open FCZs is agreed by a committee of the village that consists of a village head, two vice-headmen, a policeman, representatives of women's league, youth league and elders' league and one soldier. Other than these official members, a few people of sub-groups in the village, and some from neighboring village participated. For an example, in Bane $\mathrm{DH}$, the deep pool was opened once a year in 2003, 2004 and 2005. In 2003 and 2004, cash gained by sales of fish (1.2 millions, 1.1 millions and 0.3 millions $\mathrm{KP}$ in respective year) were used in order to purchase construction materials for a primary school. In 2005, cash was dedicated to one poor family in order for them to conduct the funeral ceremony.

In summary, a new conservation rule, vang xum xone, appears effective as community-based resource management measures, and a change from sanctuary to common property apparently merits for social integrity. At the same time, a few days fishing would be unlikely to affect fish resource.

\section{Fish conservation zone in northern Thailand}

In northern Thailand, similar practices of fish conservation have been implemented. Here, a case of Ing River, a tributary of Mekong River in northern Thailand is described. According to the survey in 2003 and 2004, 15 riverine communities of Tai and Tai Lue people along Ing river, have claimed a fish conservation zone as long as 100 to $300 \mathrm{~m}$ within the village territory throughout the year, and at the same time the conservation of inundated forest has been declared by prohibiting forest clearance in the early 2003 (Akimichi, 2004b). The decision has been resolved through a village's general meeting in order to conserve fish resources and particularly spawning grounds for migratory fish. Riparian inundated forests which line along the river bank are known to local people that they play an important role as the spawning grounds for ascending fish from the Mekong River (cf. white fish). Due to a state policy of agricultural development and population growth, riverine forests have been converted to cultivation land for maize and other cash crop since early 1990s. Agricultural use of riverine forest surely lead to a failure of fish migration between the spawning sites and Mekong River that is fatal to sustainable resource management and a life sustenance of migratory fish.

Much worse is illegal fishing operation in the upper stream of Ing River, using a wooden weir installation to induce fish into a bag net when fish descend the river in September and October. This installation (pon pan) aimed to haul especially juvenile fish. This technique is officially prohibited by national law for the resource management goal, and is apparently hazardous for the renewal of fish population. Major catch is purchased by middlemen and used for producing fish sauce or nam pla, an important ingredient in Thailand. Despite fish conservation measures practiced in some communities of lower Ing river, illegal fishing in upper stream evidently has negative impacts on fish migration. Therefore, in such a medium-sized river as Ing, the idea of river basin scale conservation must be seriously considered. Yet, the lack of governance by local fisheries office as well as collective community alliance may lead to resource depletion in near future. Negotiation with middlemen group to persuade them to stop weir fishing with a strong cooperation of local NGOs and local communities and local fishery office is vital for solving the issue. 


\section{Black fish: harvest in ponds and paddy fields in Laos and Thailand}

Unlike white fish that migrate for a long distance, black fish do not migrate but stay in the swamps, ponds, floodplains year round and seasonally enter into paddy fields in the wet season. Therefore, black fish is a good source of animal protein for peasants who cultivate paddy rice. Flooding forests also provide a variety of non-timber forest products such as mushroom, fruits, tree bark, medicinal plants, and bamboo shoots (Mollot et al. 2003)

Along Ing river in northern Thailand, there are many crescent-shaped ponds (nong) on both sides of the river. These ponds are individually named and possessed either by the community or individuals. Due to marked seasonality, the right to pond fishing is distinctively defined according to the season. During the rainy season (June to November), Mekong River inundates and flooded waters cover riparian forests and cultivated lands of the tributaries in which small-scale fishing by means of scoop net and lift net are conducted anywhere (=open access) by children and women, although it is less effective as it is not easy to search for fish in flooded areas. On the contrary, during the dry season (December through May), ponds, wetland and paddy fields become good fishing grounds where a number of fish are found.

Whether access rights to these fishing grounds are allowed or not depends on the community's decision, and community members are subject to certain rules. In communal ponds, community's rules are (1) any type of fishing is allowed for the first or second days of opening, and then allowed to any members of the community, (2) communal fishing is allowed but certain amount of entry fee is charged, depending on the fishing gear. For an example, cast net and four-diagonal scoop net are charged to use while basket and plunge basket trap are free of charge. Apart from fishing, to collect seeds, roots and flowers of lotus is generally prohibited as lotus is a good source of cash income.

In some communities, the auction system has recently been introduced and those who obtain the entry right can fish only four or five days by using any type of fishing gears (Onishi, 2008). After sixth day anyone can freely fish.

In southern Laos, pond fishing is also widespread. Ponds are principally common property pond (nong souan loame). In the driest time, communal fishing, phaa nong is conducted in which all community members take part in with such fishing gears as cast net, basket, scoop net, and plunge basket. It should be noted that pond ownership has recently been changed in some
Table 1. Use of the takings obtained by privatization (A case of NB Village)

\begin{tabular}{ccc}
\hline Sales Price $(\mathrm{KP})$ & Purpose for sale & Year \\
\hline 2.0 millions & Road construction & 2000 \\
0.2 millions & Road construction & 2000 \\
2.5 millions & Road construction & 2000 \\
1.5 millions & Electricity of the temple & 2002 \\
1.5 millions & Electric wire, timber & 2002 \\
\hline
\end{tabular}

communities since 1990s. Communal ponds have come to be sold to individuals, and claimed as private property pond (nong souan tua). The reason why village committee resolved to sell communal ponds to individuals is diverse, but in many cases an incentive is to obtain cash for community's social development. For instance, in NB village in southern Laos, five communal ponds were sold between 2000 and 2005 for creating the fund to install electricity in the Buddhist temple, and road construction (Table 1). Transaction is done by means of cash, and the income is kept by two clerks of the village for the later use (Akimichi, 2007a).

In $\mathrm{S}$ village, due to frequent poaching, communal pond fishing was less productive. Even if fish being sold to the market, income did not meet with community's need. This is the reason why village committee decided to sell some ponds to individuals to obtain a good round sum. Also, as one family newly cleared the swamp around the pond for paddy field cultivation, the village committee decided to sell the pond in order to care the family.

In $\mathrm{PH}$ village, there are two large ponds and 25 medium-sized ponds in the village territory. All the ponds are a common property of the village so that anyone can freely fish at any time, although fishing by electric device, fertilizer and draining-off fishing during the dry season (sah paa) are prohibited. A new trial commenced since around 2000s. Although ponds are a common property, some individuals started to buy all the hauled fish and sold them to a local market. For instance, one man obtained the right to purchase fish obtained from three ponds by 2.6 millions KP and sold them at Pakse market. He got 0.8 millions KP profit. Similarly, another man bought fish from one pond by 0.3 millions $\mathrm{KP}$, and he obtained 1.5 millions KP. It should be noted that the income brought to the community was devoted to public purpose. For an example, 2.6 millions KP was applied for the construction of the rest room of the temple. The idea was resolved by community's own initiative.

Property regime shift has also been observed due to another reason. In the southern skirt of Boloven plateau 
in southern Laos, there is a pond of about 1 square kilometer large. This pond was jointly used by three communities (NK, T and N) for small-scale fishing. Yet, use rights are not exclusive to these villages, but open to other neighboring villagers. Among three communities, NK can use the central part as this village has the priority because of a long occupation history of about six hundreds years. On the other hand, T community can use the eastern shallow coast while $\mathrm{N}$ community can use the western coast. Due to the introduction of irrigation system in NK community in 2002, pond-side common property area has come to be converted to paddy fields and used by poor landless families. Since then, pond fishing became inactive due to inaccessibility of the pond. This process is underway and common property of the pond might be lost. Introduction of the irrigation system clearly has triggered to induce property regime shift. Irrigation has also negatively impacted of decrease in rice yields due to prolonged flooding (Akimichi, 2007b).

As a summary of this section, I raise an illustration to overview the change in ponds ownership from a common property to a private property (Fig. 1). As is clear from the schema, drivers involved in the property regime shift are diverse. Not only autonomous village leaders' decision to sell to individuals for obtaining funds, but also one-sided enclosure for aquaculture and lotus harvest, pollution, agricultural expansion, and external forces such as the government policy,

\section{Paddy field fishing}

In Southeast Asian paddy fields, it is commonly found that any kind of subsistence pursuit in paddy fields is open access. For instance, frog hooking at the bank of paddy field, fishing by scoop net, cast net and plunge basket are able to be freely undertaken by anyone, apart from the owner of paddy field. This is due to the basic notion that rice in paddy fields is produced by humans but that fish and other plants and animal life are wild in nature, independent of human activity. Therefore, rice is claimed as private property while wild life is open access. This is

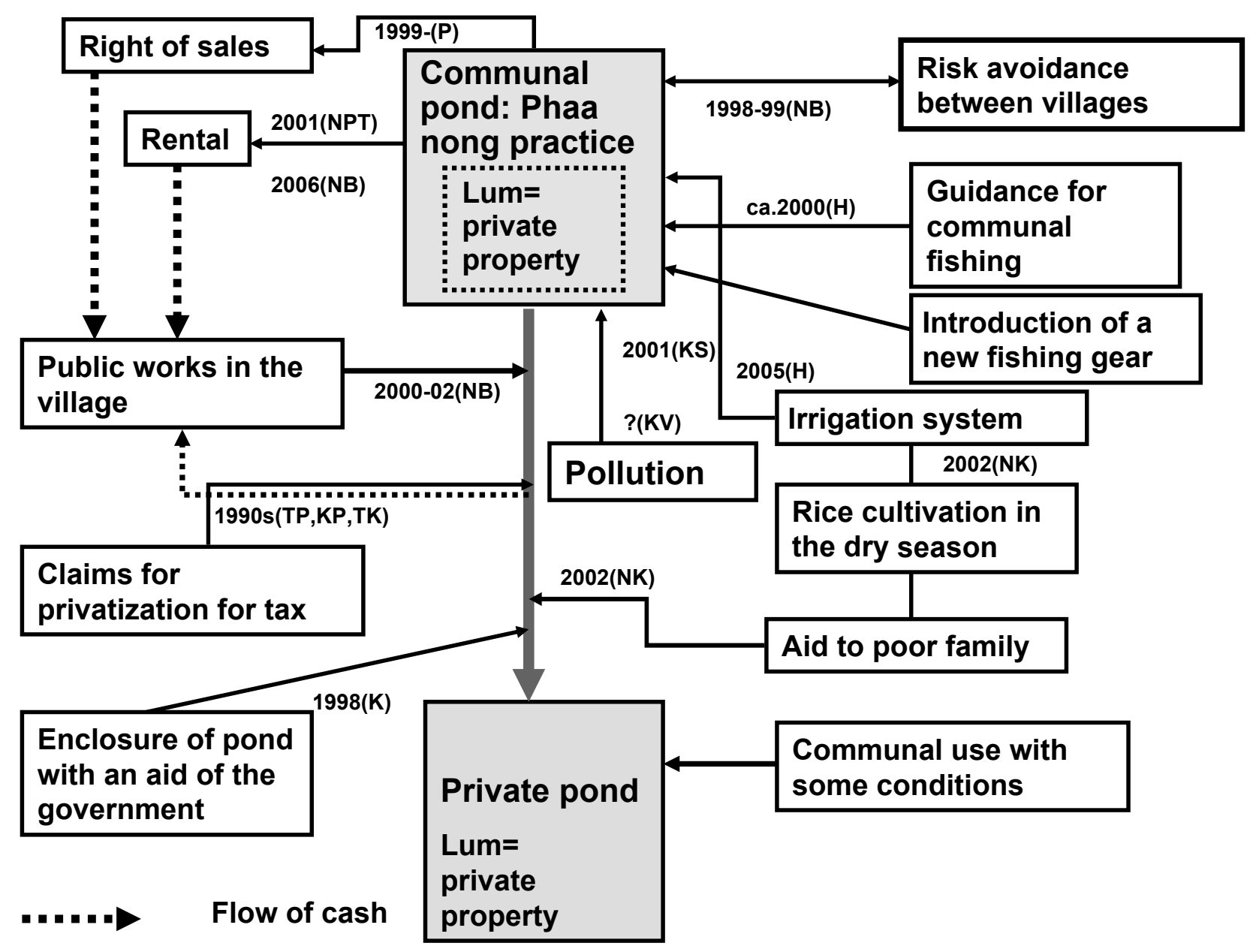

Fig. 1. Change of access rights to aquatic resources in Laos and Thailand $\mathrm{NB}, \mathrm{P}, \mathrm{NK}, \mathrm{H}, \mathrm{K}, \mathrm{TP}, \mathrm{KP}, \mathrm{TK}, \mathrm{KS}, \mathrm{KV}$ and NPT indicate name of villages. 


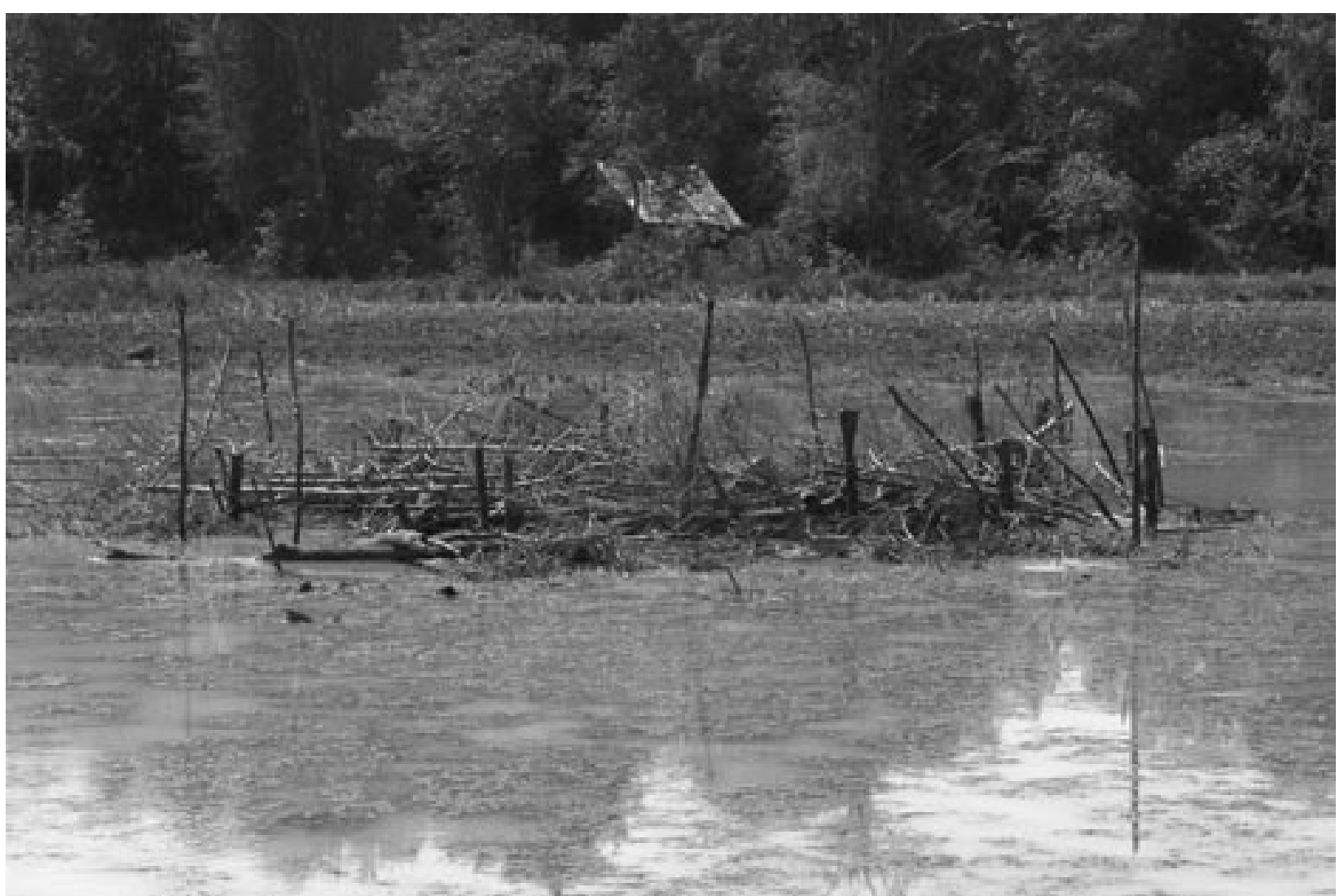

Photo 2. Lum installation in a paddy field (NB village, southern Laos)

strikingly distinct from western idea that land lord who owns forest and land can also claim ownership to wild life that live within forest.

In southern Laos, fish shelter is often constructed in ponds and paddy fields. The installation is called lum, and it is a rectangular or round shape that is about two to three meters long and three meters deep (Photograph 2). It is also known as ounlung in Cambodia (Loueung et al. 2003). Lum is a fish shelter prepared for fishing during the dry season that helps people to fish easily. This installation belongs exclusively to the people who constructed. In a paddy field, owner of rice field can construct lum while in a communal pond, anyone of the village can do so and claim the use of lum (Akimichi, 2007c). Besides the lum installation in a paddy field, people often set a basketry trap at the edge of a paddy field, especially when fish descend toward down stream. The right to set fish traps belongs exclusively to the owner of a paddy field, and not for everyone. Those who steal fish from the trap, or set a fish trap at other's paddy field are usually charged a fine as penalty. It is evident that the exit of a paddy field leading to canals is not free to use, but claimed by the owner of a paddy field. In a paddy field, the access right to fish during the post-harvest period is generally free, even without the permission of the land owner (Akimichi, 2007a).

\section{DISCUSSION}

\section{Property regime shift}

As clarified above, property regimes in freshwater domain are changing, at least in the Lower Mekong Basin of Thailand and Laos. Fish conservation zone (FCZs) program in which sanctuary is established has been partly successful but the local hegemony resolved to modify them to a common property for community development and public investment. This trend is partly associated with social change since the cease of the second Indo-China War in 1975. Laos became the People's Democratic Republic of the same year and stepped for the national development. Development has been both national and community's goal. Although fish conservation zone program aimed to conserve decreasing fish population due to over-fishing, high demand of fish in the markets, some local communities decided to open sanctuary only for a limited period. We are not sure if the voice for promoting social development may further increase the opportunity to open fish conservation zones 
more frequently than the present.

Fish conservation for migratory fish is not only a matter of community level, but seriously trans-border issue. As white fish migrate for a long geographical range, stakeholders involved are numerous in number and diverse in nature. As shown in the case of pon pan fishing in northern Thailand, conflict may occur among fishermen of the upper-stream and the down stream.

In north-eastern part of Thailand, more serious issue happened. The government constructed a dam at the mouth of Mun river (Pak Mun) that flows into Mekong River. As the dam inhibits the migration of fish toward the upper-stream, local fishermen along Mun river opposed to the closing of dam gate, and demanded to open it during the ascending and descending seasons of white fish. Local NGOs have demonstrated the importance of river fishing in the upper reaches of Mun river, showing a diversity of migratory fish species they have been utilized by local fishermen (Baird et al. 1999). After the strong protest and demonstration to the central government, Pak Mun dam was finally opened. In 2003, one Mekong giant catfish (pla beuk) was reported to be caught in Mun river, suggesting that this endangered species used to ascend the tributary of the Mekong River (Akimichi, 2008b). Also, one local fisherman along Ing river of northern Thailand, told me that pla beuk was observed to ascend the river. Dam is beneficial for a number of citizens for providing electricity as well as water for agricultural irrigation. However, there is no good reason to deny not only local fishermen's life, who depend on migratory fish populations, but also a biodiversity and the ecological system of the Mekong River Basin. Therefore, it is significant to acknowledge not only local common property, but also regional common property as is well understood from the case of longdistance migratory fish.

Ponds and reservoirs used to be a common property of the community, and phaa nong practice ensured the participation of collective owners. Phaa nong often accompanies rituals to communicate with the village guardian spirits. Since around 2000s, some ponds have come to be privatized. Concession has also been made to individuals to fish in communal ponds. Auction system has been introduced to pond fishing, and one who obtains the rights fished freely. Yet, after a few days exclusive fishing, pond was open for public use. These changes are linked with the motivation to raise funds for community development. At any rate, through communal fishing, privatized fishing by auction system, a number of black fish is exploited. Even after an annual big haul during phaa nong, seasonal flooding enables the fish recruitment that also ensures the sustainable use of the pond on the following year.

Change in property regime is also reported in other part of Laos. In Khone Island of the Mekong River, some villages still practice phaa nong while others have abandoned. Rules applied to a common property are also diverse. In one village, strict regulation is observed, but in another village, although fishing in the central part of the pond is prohibited, hooking and cast netting from the pond bank are allowed. It should be noted that privatization of ponds is undergoing not for public ends, but private motivation. For instance, in $\mathrm{O}$ village on Khone Island, one man released fingerlings in to the pond and claimed the right to fish. Similarly in another pond, one man transplanted lotus shoots in the pond and enclosed until harvest of lotus seeds (Baird, 2001). These examples suggest that privatization does not always meet with community's welfare as a whole, but means the enclosure of resource area for private purpose.

Although the decline of customary phaa nong practice is depicted since 1975, it is still observed in some villages (Shoemaker et al. 2001; Noraseng, n.d.). It should be noted that persistence of phaa nong practice may be associated with a size of pond. This is because of the fact that a large pond can sustain a large number of fish resources, and fished by a number of people cooperatively. Furthermore, a large pond is worth an expensive property to purchase. If so, property regime shift may occur in two directions in terms of an economic reason; a large pond remains as a common property while a small pond tends to be privatized.

Ponds utilized by more than one community give another example of property regime shift. We have already seen that in a large pond utilized communally by three villages, property shift has recently occurred. Similarly in Sedon river, one of the Mekong tributary, a large pond ( $1 \mathrm{~km}$ X 210 meters) used to be a common property shared among seventeen villages. Since 1998, one village declared to monopolize fishing rights of the pond with a political support of the government. Since then, people from neighboring sixteen villages were excluded (Tubtim, 2001).

Change in the FCZs in the Lower Mekong Basin and in ponds in Laos and Thailand demonstrate that property regimes are not fixed, but are flexible (Fig. 2). It is a question for the future whether a community's decision to change local property regimes is appropriate or not, and whether local people may sacrifice fish resources to social development. Also, the process of pond privatization should be carefully examined as the change involves two 


\section{$\leftarrow-\rightarrow$ Competitive Relations}

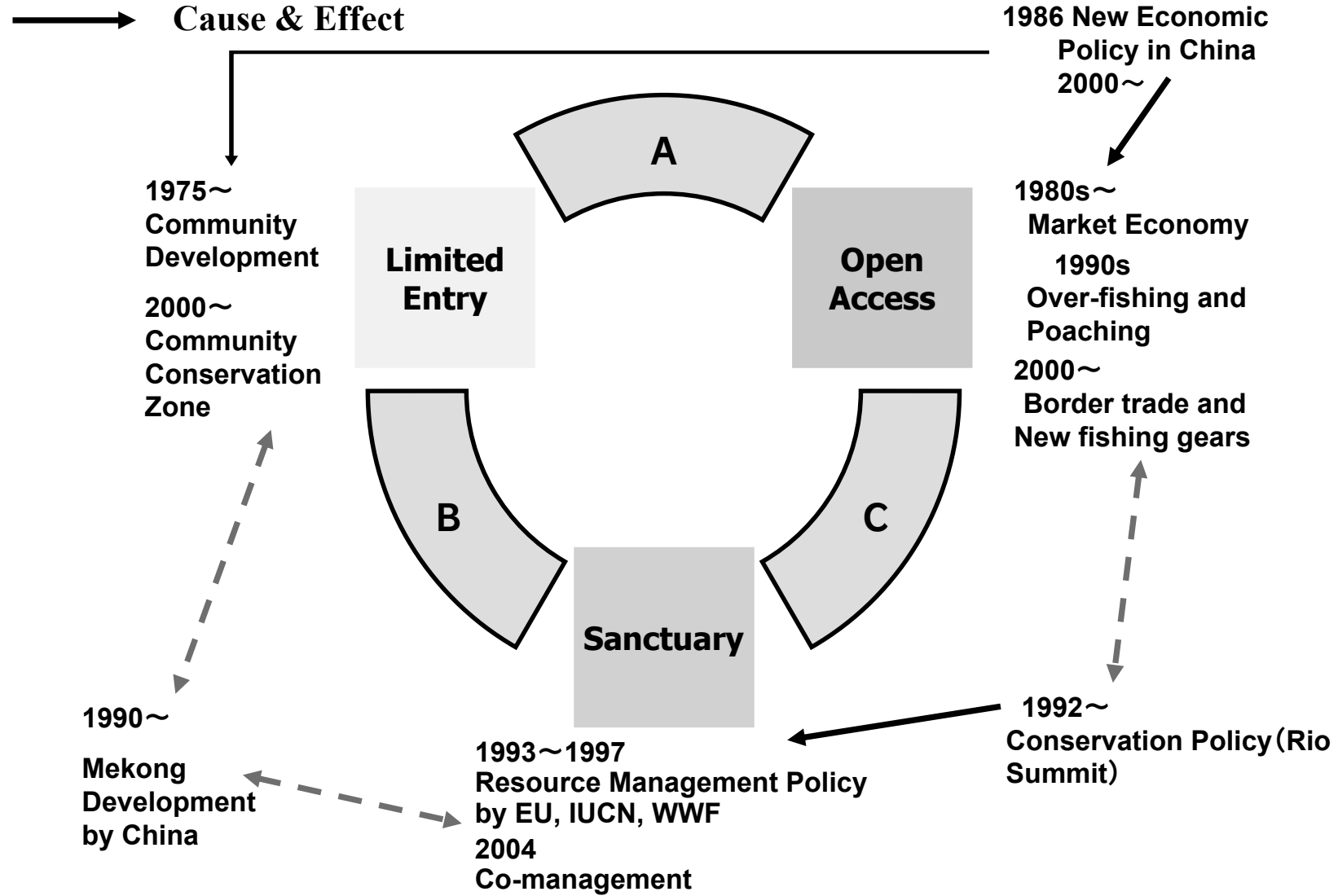

Fig. 2. A diagram to illustrate changing aspects in the property regime in the ponds, southern Laos.

distinct ways; on behalf of community welfare, otherwise the private enclosure. In either case, local hegemony plays a significant role in deciding the future of a common property.

ACKNOWLEDGEMENTS I am deeply indebted to Bounthong, B., National Institute of Agriculture and Forestry, Ministry of Agriculture, Forestry and Livestock, Lao Government, and Yos Santasombat, Faculty of Social Sciences, Chiang Mai University to continuously support my fieldwork in southern Laos and northern Thailand. I also thank to Toung, Osamu Hashimura, Hideyuki Onishi, Sayoko Iinuma for their supports during my fieldwork. This study is supported by the Research Project (4-2) by Research Institute for Humanity and Nature, Kyoto, Japan, and International Scientific Research Program (No.14083101) by Ministry of Education, Culture, Sports and Technology.

\section{REFERENCES}

Akimichi, T. 1995 Maritime Ethnology. Tokyodaigaku Shuppankai, Tokyo (in Japanese).

Akimichi, T. 2004a Anthropology of the Commons; Culture, History and Ecology, Jinbun-shoin, Kyoto (in Japanese).

Akimichi, T. 2004b Freshwater resource use in Ing and Kok rivers in northern Thailand and a proposal of the monsoon model. In: Annual Report on a TransDisciplinary Study on the Regional Eco-History in Tropical Monsoon Asia: 1945-2005, pp.13-24, Research Institute for Humanity and Nature, Kyoto (in Japanese).

Akimichi, T. 2006 Inside and outside views of resource management. In: Arasaki, M., Higa, M., \& Yanaka, S. (eds.), Autonomy of the Area and Empowerment of the Islands, pp. 225-246, Komonzu, Tokyo (in Japanese).

Akimichi, T. 2007a. A Horizon of the Resource and the Commons, In: Uchibori, M. (ed.) Resources and People, pp.209-240, Kobundou, Tokyo (in Japanese). 
Akimichi, T. 2007b. Flood and life in transition- Impacts of irrigation upon rice cultivation in Lao Lum communities in Champassak in southern Lao PDR. In RIHN $1^{\text {st }}$ International Symposium ProceedingsWater and better Human Life in the Future, pp.11-16, Research Institute for Humanity and Nature, Kyoto.

Akimichi, T. 2007c. Ownership of ponds in Asia monsoon region. In: Akimihci, T. (ed.) Resources and the Commons, pp.245-278, Kobundou, Tokyo (in Japanese).

Akimichi, T. 2008a. The eco-history of fishery resource management in the Mekong watershed. In: Akimichi, T. (ed.), The Eco-History of Livelihood and Human Body, pp. 209-228, Kobundou, Tokyo (in Japanese).

Akimichi, T. 2008b. Resource management and Mekong River development In: Akimichi, T. \& Kurokura, H. (eds.), People and Fish Living with Great Mekong River, pp. 237-249, Sekaishisosha, Kyoto (in Japanese).

Baird, I. G., Inthaphaisy, V., Kisouvannalath, P., Phylavanh, B. \& Mounsouphom, B. 1999. The Fishes of Southern Lao. Lao Community and Dolphin Protection Project, Ministry of Agriculture and Forestry, Vientiane.

Baird, I. G. \& Flaherty, M.S. 1999. Fish Conservation Zones and Indigenous Ecological Knowledge in Southern Laos: A First Step in Monitoring and Assessing Effectiveness, Environmental Protection and Community Development in Siphandone Wetland, Champassak Province, Lao PDR, Project report Project Lao/B1-B7/6200-IB/96-012, CESVI Cooperation and Development, Vientiane.

Baird, I. G. 2001. Towards sustainable co-management of Mekong River aquatic resources: The experience in Siphandone wetlands. In Daconto, G. (ed.), Siphandone Wetlands, Environmental Protection and Community Development in Siphandone Wetlands Project, pp. 89-111, Bergamo.

Claridge, G., Sorangkhoun. \& Baird, I.G. 1997. Community Fisheries in Lao PDR: A Survey of Techniques and Issues. (IUCN Lao PDR Technical Report 1), IUCN.

Cole, D. H. 2002. Pollution and Property-Comparing Ownership Institutions for Environmental Protection. Cambridge University Press, Cambridge.

Daconto, G. ed. 2001. Siphandone Wetlands. Environmental Protection and Community Development in Siphandone Wetlands Project, Bergamo.

Loeung, D., Degen, P. \& Zalinge, N. van 2003. Fishing
Gears of the Cambodian Mekong, pp. 146-147, Mekong River Commission, Department of Fisheries of Cambodia, and DANIDA, Phnom Penh.

Mekong River Commission 2002. Fish Migration of the Lower Mekong River Basin: Implications for Development, Planning and Environmental Management. (MRC Technical Paper No. 8), Mekong River Commission, Vientiane.

Mollot, R., Phothitay, C. \& Kosy, S. 2003. Hydrology, Habitat and Livelihoods on the Floodplains of Southern Lao PDR. Proceedings of the $6^{\text {th }}$ Technical Symposium on Mekong Fisheries, pp. 155-176, (MRC Conference Series No. 5), Mekong River Commission, Vientiane.

Noraseng, P., Manotham, S., Hirsch, P. \& Tubtim, K. n.d. Seasonal Backswamps and Small Water Body Management: Natural and Financed Indigenous Fisheries. (Indigenous Fisheries Development and Management Project Technical Report 4), Department of Livestock and Fisheries, Ministry of Agriculture and Forestry, Lao PDR, Vientiane.

Onishi, H. 2008 Logic of resource management in the Ing river, northern Thailand, In: Akimichi, T. \& Kurokura, H. (eds.), People and Fish -Living with Great Mekong River, pp. 220-236, Sekaishisosha, Kyoto (in Japanese).

Poulsen, A. F., Hortle, K.G., Valbo-Jorgensen, J., Chan, S., Chhuon, C.K., Viravong, S., Bouakhamvongsa, K., Suntornratana, U., Yoorong, N., Nguyen, T.T. \& Tran, B.Q. 2004. Distribution and Ecology of Some Important Riverine Fish Species of the Mekong River Basin. (MRC Technical Paper No. 10), Mekong River Commission, Vientiane.

Shoemaker, B., Baird, I.G. \& Baird, M. 2001. The People and their River: A Survey of River-Based Livelihoods in the Xe Bang Fai River Basin in Central Lao PDR, Lao PDR/Canada Fund, Vientiane.

Tisdell, C. 1999. Economics, aspects of ecology and sustainable agricultural production. In: Dragun, A. K. \& Tisdell, C. (eds.), Sustainable Agriculture and Environment, Globalization and the Impact of Trade Liberalization, pp. 37-56, Edward Elgar, Cheltenham.

Tubtim, K. 2001. Common Property as Enclosure: A Case Study of a Community Backswamp in southern Lao PDR. (Master Thesis), Chiang Mai University, Chiang Mai.

Welcomme, R. 1985. River Fisheries. FAO Technical Paper No. 262, FAO, Rome.

Received $9^{\text {th }}$ Feb. 2007 Accepted $1^{\text {st }}$ Aug. 2008 